\title{
SCENARIOS AND THEIR APPLICATION IN STRATEGIC PLANNING
}

\author{
Emil Vacík, Jiří Fotr, Miroslav Špaček, Ivan Souček
}

\section{Introduction}

The impetus for the origin and development of scenarios or scenario thinking were failures of many strategic decisions based on one projection of the future, specifically on values of fundamental factors which influence consequences of these decisions. A great deal of attention has been paid to scenarios since the 70 s of the past century. The company Shell was a pioneer of the scenario approach in the strategic decision-making process. Heiden [17] points out that since the 80 s of the past century Shell has insisted on the evaluation of every important project against the set of scenarios elaborated. Since then scenarios have become an important tool of creative thinking development when considering possibilities of the future development. Similarly, scenarios became an important tool of decision support, especially of strategic nature. Over the past years scenarios were applied stepwise even in the Czech Republic. Contemporary methods of scenarios construction work on need to ensure flexibility of the strategic plan and get the firm ready for a quick reaction when setting trigger points specifying the corresponding scenario which come to pass. Processing business environment information, known as Business Intelligence, becomes necessity. Strategic scenarios contain approaches of strategic planning, risk management and managerial decision. At the same time demands on the CEO staff grow. Apart from experience and intuition relevant knowledge foundation and work with information sources creates important managerial competences. The goal of this article is to describe the scenario formation methodology in strategic planning processes and to discuss their possible impact on meeting company's strategic goals. Finally, the impacts of risks on strategic planning processes are exemplified by a business case.

\section{Scenario Concept}

The concept of scenarios is not uniform. The existing differences are usually reflections of the use of decision aspects in scenarios, which are applied to a different extent. It deals with mixing possibilities of external environment development which is not usually influenceable or partly influenceable by the decision-making subject on the one hand and an intentional selection of a certain action variant by this subject on the other hand.

The former concept is prevalent in professional literature. According to Gugan [15], scenarios provide alternative views of the future. They identify some fundamental events, key players and their motivation and offer different perspectives of the future world development. The development and application of scenarios are thus conducive to searching for ways how to challenge future uncertainties. According to Schoemaker [29], scenarios represent internally consistent pictures of the future which are based on a certain group of mutually interlinked factors of both a qualitative and quantitative nature. As per Schoemaker, the starting point of their formation should be specification of what we know about the future development, such as trends, on the one hand and specification of what we do not know, such as key uncertainties, on the other hand. Every scenario is then based on interconnection of these trends and uncertainties. An analogical concept is held by Foster [7]. According to him, scenarios represent a certain picture of the future which combines qualitative and quantitative characteristics. According to Pearson and Lyons [26], the scenario formation 
comes out of factors which are both uncertain and have a key impact on the system. As per Tessun and Hermann [30], scenarios identify the key driving forces of the development including their mutual dependences which are further tied with existing opportunities and risks. Van der Heijden [18] supports and adheres to the same concept of scenarios. Scenarios, as opposed to usual prediction methods, are focused on the identification of discontinuities in the development and help the organization cope with sudden changes and noticeably contribute to its survival. They enable not only a better understanding of the possible vulnerability of a company, but they are also conducive to its optimum strategic orientation.

\section{Development of Scenarios for the Support of Strategic Planning}

The incentive to working with scenarios is the formulation of company vision. Strategic management vision is understood to be an exact and structured expression of company status in a defined future time horizon. Since the strategy represents a basic planning document, it must be formulated both exactly and consistently in all partial components in order not to lose meaning in its entirety. The planning horizon is usually mid-term but this determination is contingent both upon the character of the business (e.g. pharmaceutical industry, energy industry or capital construction have longer planning horizons) and the development of economic cycle which influences the relevancy of predictions. Even if vision contains all initial information, yet it has to have necessary breadth and depth to become a tool for long-term strategic goals determination. While adhering to these goals and respecting the vision content, strategic grounds are consequently deduced. These grounds describe the requested shift of the company towards target position defined on the basis of all available and known information including demands and attitudes of key stakeholders. It is conditional for the success of scenario elaboration that all important stakeholders concerned would not have objections to scenarios content and their application.

The very process of scenario elaboration can be split into six basic steps:

- Identification of risk factors and determination of their importance.
- Selection of key risks which, according to the company's opinion, fundamentally influence fulfilment of strategic goals.

- Formulation of basic scenarios and testing their consistency.

- Determination of probability of scenarios occurrence.

- Performing a "gap analysis" for the sake of determining the extent of strategic goals fulfilment.

\subsection{Identification of Risk Factors and Determination of Their Importance}

Identification of risks is a process upon which factors that can influence strategic grounds negatively or positively are determined. (It is important to emphasize that we do not understand risks only as the negative ones - threats, but also the positive ones - opportunities).

Quality and reliability of scenarios composed depend on the quality and extent of information collected and processed. Business Intelligence represents a complex method which is aimed at obtaining and analysing supportive information about the business environment in its entirety. The nature of this method is processing and analysing publicly available and verified data, which include government information and documents, web sites, business presentations, advertisements, interviews, surveys, financial reports, business meetings, exhibitions, company managers' and speakers' statements (competitors, suppliers, distributors, customers etc.) [13].

In order to apply the Business Intelligence concept, variety of methodological approaches and tools of data collection and analysis techniques, such as SWOT, competitors' profile, benchmarking, environment development modelling, sectorial, financial and Win/Loss analyses, are used. It typically deals with retrospective analyses which are performed mostly after important capital transactions either between various business subjects or state and these subjects. The objective of these analyses is to find out whether these transactions were successful or not and why [14].

In view of the numerous risks to be usually identified there is necessity to restrict them to several key risks which play the role in scenario development. Furthermore it is necessary to judge the significance of these risks. Risk 
assessment matrix or sensitivity analysis (supposing that risks are quantifiable) may be used as supportive tools. [12].

Risk assessment matrix is a tool of an expert evaluation of risk importance which is based on two aspects. The first one is the risk occurrence probability and the second one is the strength of its impact on the firm (usually in a form of chosen financial indicator, which can be profit, cash flow etc.). The outcome of risk assessment matrix is the list of key risks that are characterized by both high probability of occurrence and high importance of the impact.

The nature of sensitivity analysis is testing impacts of equal relative deviations (e.g. $10 \%$ ) of risk factors (sales, selling price, raw material purchase prices, energy prices, exchange rates) from their most probable values on the company's key performance criteria (profit, EVA, ROI etc.). The outcome of the analysis is then the identification of factors to which the selected criterion of strategic plan evaluation is highly sensitive. These factors then widen the set of key risks.

Finally, it is necessary to point out that risks may create a causal chain. At the one end of this chain there are sources (causes) of the risk or risks which are close to this source, while at the other end there are risks which are close to their impacts. For example, the war conflict in the Near East can be close to causes of the increase in prices of crude oil. The increase in crude oil prices results in the gasoline price increase as well as in the price increase of other crude oil products, which are regarded as raw materials for the petrochemical industry. The increase in gasoline price implies the increase in transportation companies' service prices (or the decrease in their profit supposing that they fail to increase the service prices). These service prices then have an impact on transportation costs of companies which consume these services etc. When elaborating scenarios for strategic planning of the respective subject, e.g. an industrial company, it is necessary to work with such risks that are in such a position of the causal chain where they can be transferred relatively easily to financial plans. For these risks it is also possible to determine a probability distribution. As far as transportation companies are concerned, such factors might be the crude oil price and the exchange rate of
USD/CZK, since USD is a currency in which crude oil prices are purchased.

\subsection{Formation of Representative Scenarios and Testing Their Consistency}

Scenario formation comes out of key risks. The number of these factors must be restricted so that too many scenarios could not come into existence. Excessive number of scenarios would hamper their application. The simplest case is the existence of the two most important binary risks, which implies four possible scenarios. To describe scenarios consisting of two risks a scenario matrix with an advantage is used. This matrix enables us to make an analysis of the interaction among key risks. It is commonplace that one of the scenarios represents the most probable development of environment. This scenario is usually designated as a basic scenario. The remaining scenarios explicate other possible, but as a rule, less probable alternatives of the future development.

It is possible to arrive at the same results by means of probability trees [11], or event trees [5], which are, however, suitable in a situation where more risks exist or these risks exert their effects gradually. It is worth mentioning that the probability or event trees deal with discreet risks. In case of continuous risks it is inevitable to approximate their continuous distribution curve by the stepwise one [11] and consequently work with several values of these factors which represent a single continuous risk. The advantage of the use of probability trees in scenario planning consists in the tree construction simplicity, its transparency, comprehensibility and the depiction of conditional development of risks. The undisputable benefit is that there is no need to foresee the end of the event and by means of this technique it is possible to identify weaknesses of the system. The disadvantage, which is usually attributed to the use of probability and event trees, is their discreet character and low number of risks, which can be subjected to analysis, since the tree has to remain illustrative.

In practice analysts usually work with a few scenarios that represent certain real and possible developments of key risks. In company strategic planning the following scenarios are usually applied: 
- Optimistic scenario, where other existing opportunities utilized by the internal potential of the company are taken into consideration. The optimistic development offers assumption that goals which have been set down will be exceeded.

- Basic (the most probable) scenario is based on the most probable development of key risks.

- Pessimistic scenario, where circumstances and trends resulting from threats identified are taken into account. The company cannot usually cope with these threats by its internal potential and consequently it is supposed that goals determined will not be fulfilled.

In crisis management an extremely unfavourable development which results in warning and alert scenarios, which are based on the highly pessimistic development of respective risk components, is taken into consideration.

Scenario testing represents the process of examination of their consistency, which means the rationality of assumptions chosen as well as the viability of scenarios. Scenarios are subjected to critical logical analysis with the aim to judge their meaning within the group of their authors. Besides logical analysis, even intuitive approaches are not excluded from the testing process. As long as the scenario proves not to be inherently consistent, it is necessary to answer the question: "What is the cause of it?" The usual problem is that one or more assumptions prove to be unrealistic. In such a case it is necessary to revert to the very beginning and redefine assumptions and by means of the iterative process to arrive at a stage when scenarios elaborated are sufficiently consistent.

\subsection{Scenario Probability Determination}

In case of relatively simple scenarios it is possible to determine their probabilities. When applying probability trees to scenarios depiction, it is necessary, especially in view of the frequent dependency of individual risks, first of all, to determine the unconditional probability distribution of risks, which is portrayed by the chance node positioned on the far left side of the tree. It is the root of the tree. Furthermore, the conditional probability distribution of risks portrayed by nodes situated on the right side of the tree root has been determined stepwise. This process is continued until we arrive at risks portrayed by the node which is situated on the far right side of the tree. The probability of each scenario is then calculated as multiplication of risk probability values which are situated on the same branch of the probability tree. (We encounter an analogical situation in the scenario matrix application which can easily be transformed into a simple probability tree).

Probabilities of risks do not usually have the character of objective probabilities determined on the basis of historical data by means of statistical methods. It deals prevalently with subjective probabilities, which are based on experience, intuition and information background of these experts [6].

\subsection{Performing a "Gap Analysis" to Evaluate the Scope of Fulfilment of Strategic Goals Formulated}

The scenarios discussed were composed on the basis of key risks and probabilities which may come into effect. Now it is necessary to examine the performance efficiency of strategic plan variants in individual scenarios and compare them with the originally formulated strategic grounds. This process is called a "gap method" and its essence is the identification of the so-called Planning Gaps. A Strategic Gap then represents the difference between the strategic goals planned and the development of the variant in the respective scenario. The incentive to performing a Gap Analysis is the examination of the need for a strategic action also in the stage when the strategic plan variant is still correctable. This approach is more effective than performing non-conceptual changes at the level of operational management. A continuous assessment of the fulfilment of key performance indicators during the strategy implementation is a basic requirement for the effective execution of the strategic control which is closely combined with the scenario approach. Moreover, an effective transformation of a strategy into a fundamental strategic plan as well as the observation of risk development and the possibility of assessing the risk impact on the strategy are also prerequisites for a successful gap analysis. 


\section{Application of Scenarios for the Support of Strategic Planning in Practice}

The most important area of scenarios application in a business company is strategic planning and decision making. Scenarios can be conducive to:

- elaboration of strategic plan variants (hereinafter referred to as "strategic variants"),

- assessment of strategic variants,

- risk management.

The application of scenarios as a tool for the support of strategic variants formulation comes out of the assumption that scenarios illustrate different possibilities of the external environment development and provide thus incentives to the consideration of possible fundamental ways of reaction to a different development of this environment. This prerequisite then supports the formulation of some strategic variants. These variants are not merely quantitative modifications of one strategic variant, but they differ substantially by their nature.

Scenarios play an important role in the evaluation of strategic variants and their risk assessment [25]. The fundamental assumption is that each variant should be tested at all scenarios. It means that for each strategic variant and each scenario the impacts with regard to the individual criteria assessment should be determined. The financial plan elaboration for each variant and scenario shall be considered as a basis for the determination of these impacts, which are usually expressed by means of the key financial criteria. Values of these and other criteria, which account for possible results of individual variants in all scenarios, then enable us to judge risk size of individual variants and acceptability of such a risk.

For this purpose the following techniques can be used:

- Scope of possible results of strategic variants with respect to individual criteria. The wider these intervals are, the higher risk is recorded. A relatively narrow scope of values points out that the results gained in all scenarios are not significantly different. It indicates that the strategic variant in question is considerably robust (as a matter of fact it deals with the variant for general application).
- Strategic variant results obtained in a pessimistic or warning scenario. It deals preferably with the assessment of financial stability (commercial viability) of variants which rests on the examination of the company's ability to repay its liabilities used for the financing of the respective strategic variant in the considerably unfavourable development of business environment. In case of known scenario probabilities, numeric risk characteristics of strategic variants with respect to quantitative criteria, such as the variance, the standard deviation or the coefficient of variation may be used.

The decision about acceptance or refusal of certain strategic variants would be simple providing that the variants in question are economically effective with the acceptable risk exposure even in a pessimistic scenario and vice versa - economically ineffective in an optimistic scenario. It is obvious that this situation is very rare in business practice. Another situation which is also very rare is that a certain strategic variant arrives at the best results in all scenarios. Such being the case, then a dominating variant exists. As long as this is not the case, the selection of a strategic variant based on the aforementioned information about the risk size depends, to some extent, on managers' or company's attitudes to risk.

In strategic risk management both a timely preparation of provisions aimed at minimizing the negative impacts of business environment development, which is in consonance with the pessimistic or warning scenario, and a preparation of provisions that enable us to take the opportunity and to reinforce the positive impacts of the development to be in agreement with the optimistic scenario are important. To examine whether the business environment development proceeds in accordance with a certain scenario, early warning systems are used. For each factor included in a scenario, certain limit (signal) values should be determined. These values become indicators of the environment development showing conformity of this development with the particular scenario. When the actual development deviates from signal values, then it is necessary to repeatedly analyse the environment development and correct or update the set of scenarios formulated. Early warning systems should also draw attention to substantial changes in other 
factors which have not been included in the scenario formulation so far and in this way to initiate their possible integration into scenarios.

\section{Case Study on the Scenario Application in the Elaboration of the Strategic Plan of a Particular Company}

\subsection{Company Vision and Mission}

The scenario approach was verified in practice by means of the elaboration of the strategic plan of a mid-sized machinery company which is active in the machine tool segment. The objective of practical verification of the scenario application was:

- elaboration of the set of three scenarios,

- evaluation of the initial variant of strategic plan in these scenarios,

- application of strategic management tools.

The company's vision for 2015 was formulated as follows:

"Our machinery company wants to continue providing customers with high quality products which are of in-house development as per their requirements. Our company wants to invest into innovation (rationalisation) over the next three years, which enables the increase in product prices by means of product quality improvement and consequently the increase in company sales.

Besides the Czech market, the company wants to draw attention to foreign markets where our company will strive for strengthening its position in the Russian market as well as for entering new markets in other countries of the former Soviet Union, where the contacts have already been established. At the end of the planned period the company wants to close a contract for the supply of one machine per year to the Ukraine, Belorussia and Kazakhstan. In the sphere of human resources the working team is stabilised as far as their technical and qualification skills are concerned. Therefore, the emphasis is placed on the employee motivation and education, especially in the sphere of language skills. The company will reinforce its goodwill and reputation and will continuously present itself at four world fairs a year."
The strategic plan for the three-year planning horizon covering the period of 2013-2015 came out of these mid-term strategic goals that have been determined as follows:

- By the end of planned period to invest into innovation and upgrading of current technological facilities. Capital expenditure should not exceed CZK 38M.

- By means of quality improvement and a new portal centre, company sales will rise at least by $30 \%$. Strengthening of our position in the Russian market by means of establishing a service centre, which should generate not only a competitive advantage, but also time and costs savings. Respective costs should not exceed CZK 2M.

- Closing a contract for the construction of one machine per year for the Ukrainian, Belorussian and Kazakh markets.

- Achieving the return on sales indicator value $(R O S=E B T /$ sales $)$ above $5 \%$.

- Retaining the above-standard remuneration for key employees as compared to competitors.

\subsection{Identifying Risks and Determining Their Significance}

The analysis of business environment resulted in the identification of risks mentioned in Tab. 1. These risks are ranked according to the fact whether they are negative ones (threats) or positive ones (opportunities). The first seven factors account for threats, while the last three factors represent opportunities. Tab. 1 shows the evaluation of the importance of each factor which is determined as a multiplication of expert assessment of probability of its occurrence and the importance of impact on the company. (In both cases the scale 1-5 was used, where level 1 corresponds to the lowest probability or the lowest importance, while level 5 corresponds to the highest probability or the highest importance of the impact). As a borderline, which separates less important risks from more important ones, evaluation 10 was chosen. Risks that were evaluated higher than 10 represent key risks which are manifested as threats and opportunities. 


\section{Tab. 1: Evaluation of the importance of risks identified}

\begin{tabular}{l|c|c|c|c} 
Risk factor & $\begin{array}{c}\text { Probability of } \\
\text { occurrence }\end{array}$ & $\begin{array}{c}\text { Severity of } \\
\text { impact }\end{array}$ & $\begin{array}{c}\text { Total } \\
\text { value }\end{array}$ & $\begin{array}{c}\text { Key } \\
\text { risks }\end{array}$ \\
\hline Failure of technological equipment & 2 & 4 & 8 & NO \\
\hline Increase in minimum wages & 4 & 3 & 12 & YES \\
\hline Decrease in production quality & 3 & 2 & 6 & NO \\
\hline Increase in sub-supplies prices & 3 & 4 & 12 & YES \\
\hline Availability of innovation sources & 2 & 1 & 2 & NO \\
\hline A great deal of competitors entering foreign markets & 4 & 3 & 12 & YES \\
\hline Saturation of demand for machines in the Czech market & 4 & 4 & 16 & YES \\
\hline Legislation changes with the impact on energy prices & 5 & 3 & 15 & YES \\
\hline Increase in government investments for the development & & & & \\
of technologies in Russia, Belorussia and the Ukraine & 4 & 4 & 16 & YES \\
\hline Increasing demand for machines in Kazakhstan & 3 & 2 & 6 & NO \\
\hline No local competitors in the Russian market & 3 & 2 & 6 & NO \\
\hline
\end{tabular}

Tab. 1 shows that six risks out of eleven represent key risks with the prevalence of negative risks. These negative risks (ranked as per their importance) include saturation of the demand for machines in the Czech market, legislation changes with the impact on energy prices, the increase in minimum wages, the increase in subcontract prices and a great deal of competing companies entering foreign markets.

\section{Saturation of demand for machines in the Czech market}

The company made a point of fulfilling production capacity every year and closing eight contracts for the production of new portal centre at least. The company sees as a reality closing 2-3 contracts in the Czech market and, therefore, it would have to close 5-6 contracts in foreign markets. In view of the possible saturation of the demand for machines in the Czech market, a situation when the company does not close the requested number of contracts and does not fulfil its production capacity may occur. Such a situation leads to the decrease in sales of own products and services. Low sales have a negative impact on the company's profits.

\section{Legislation changes affecting energy prices}

In accordance with the increasing production the energy costs are also rising and, therefore, the increase in energy costs has a negative impact on the company. In accordance with the fiveyear price prospect of electric power in the Czech Republic the company expects a relatively moderate rise in electric energy by approx. $8 \%$ in the planned period. There are, however, significant risks of possible legislation adjustments, such as the extent of the state subsidy for renewable energy sources and the consequent impact on prices regulated by the Energy Regulatory Office.

\section{Increase in minimum wages}

The human capital represents a crucial internal factor for the company, since they acquired important know-how. A possible loss of key employees would create a huge problem for the company. Employees' assessment is also linked with the maximum utilization of human capital. The company has to secure wages to be permanently above the average and also competitors' ones, so that the company's stability in the planned period would also be secured. Along with the increase in minimum wages a permanent rise in other employees' wages should be expected.

\section{Increase in subcontract prices}

In the long run the company has established a selected supplier network from whom it purchases material and component parts on a contractual 
basis. Material prices are fixed in advance with regard to supply volumes demanded. The advantage is possible volume discounts when purchasing higher quantities. On the other hand, there is a danger of a supply price increase when the production capacity is not fully utilized and a lower volume is purchased. This inevitably implies a negative impact on costs and material consumption.

\section{A great deal of competing companies entering foreign markets}

The portal centre market is highly competitive, especially due to the German companies operating in this segment. In case the company fails to challenge competitors and does not close the requested number of contracts to utilize its production capacity, the decline in sales and profit will be recorded.

The only important opportunity is represented by the increase in government investments for the development in countries of Russia, Belorussia and the Ukraine. In the next three years the company plans to focus more intensively on the Russian market, where it wants to grab at least four contracts per year for the production of a new portal centre. At the same time the company plans to enter new markets of the former Soviet Union countries, such as Belorussia, the Ukraine and Kazakhstan, for which the company has set a goal to close one contract per year. One of the favourable risks is the government investments in the technology development in Russia, Belorussia and the Ukraine which are expected to rise in the reporting period. The investments can increase demand for machines and consequently increase the sales and profits.

The above-mentioned key risks influence the sales volumes, selling prices and costs. This is reflected in the company's revenues and profits with the impact on financial indicator values. The mutual links of these factors illustrated by a cognitive map are shown in Fig. 1 (A plus sign in the connecting line depicting the dependency of these factors means that the increase in the factor from which the connecting line comes out causes a growth of the factor to which the connecting line is directed. A minus sign means an inverse relationship where e.g. the increase in demand saturation in the domestic market results in the decrease in sales and selling prices.

\section{Fig. 1: Cognitive map}

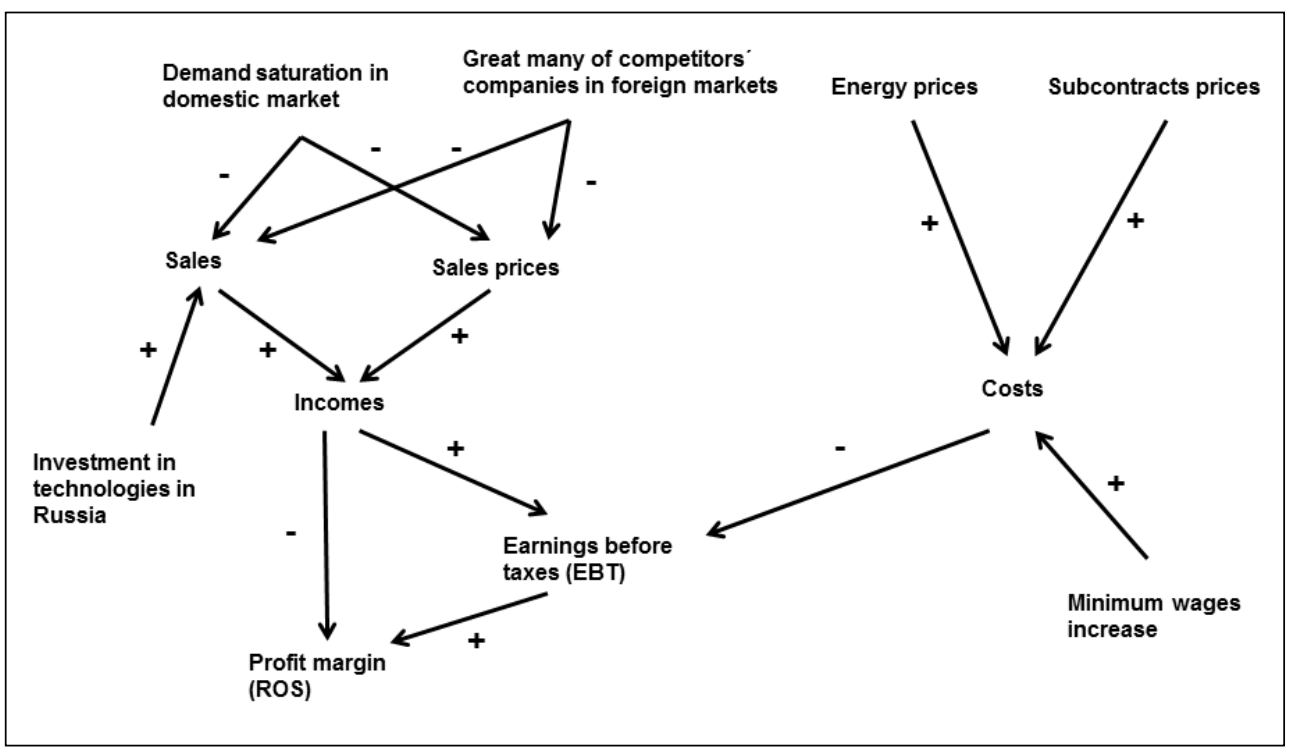


The results of sensitivity analysis of the company's profit in 2013 support the importance of the identification of key risks or opportunities.
Negative changes at the same $10 \%$ in individual costs and revenues items from their planned values are shown in Tab. 2.

\section{Tab. 2: Results of the sensitivity analysis of the company's profit after tax}

\begin{tabular}{l|c|c|c|c|c} 
& $\begin{array}{c}\text { Planned } \\
\text { value } \\
\text { [thous. CZK] }\end{array}$ & $\begin{array}{c}\text { Change } \\
\text { by } 10 \% \\
\text { [thous. CZK] } \\
\text { [thous. CZK] }\end{array}$ & $\begin{array}{c}\text { EBT } \\
\text { change in } \\
\text { EBT } \\
\text { [thous. CZK] }\end{array}$ & $\begin{array}{c}\text { Relative } \\
\text { change } \\
\text { in EBT } \\
\text { [\%] }\end{array}$ \\
\hline Sales of own manufactured products and services & 215,000 & 193,500 & $-15,717$ & $-21,500$ & -371.77 \\
\hline Material consumed in production & 109,564 & 120,520 & $-5,173$ & $-10,956$ & -189.46 \\
\hline Energies consumed in production & 30,186 & 3,305 & 2,764 & $-3,019$ & -52.20 \\
\hline Services & 27,870 & 3,057 & 2,996 & $-2,787$ & -48.19 \\
\hline Personnel costs & 36,188 & 3,907 & 2,164 & $-3,619$ & -62.58 \\
\hline Taxes and charges & 47 & 52 & 5,778 & -5 & -0.08 \\
\hline Depreciation of fixed assets (tangibles \& intangibles) & 6,508 & 7,159 & 5,132 & -651 & -11.25 \\
\hline Income from sales of fixed assets and materials sold & 5,000 & 4,500 & 5,283 & -500 & -8.65 \\
\hline Other operating earnings & 1,441 & 1,296 & 5,639 & -144 & -2.49 \\
\hline Other operating costs & 1,257 & 1,483 & 5,557 & -226 & -3.90 \\
\hline Interest expenses & 1,985 & 3,184 & 5,585 & -199 & -3.43 \\
\hline Other financial income & 1,313 & 1,182 & 5,652 & -131 & -2.27 \\
\hline Other financial costs & 1,365 & 1,602 & 5,547 & -237 & -4.09 \\
\hline Earnings before taxes (EBT) & 5,783 & & & & \\
\hline
\end{tabular}

The above-mentioned table shows that the highest decline in the company's Earnings Before Taxes - EBT (by 372\%) caused a drop in sales of own manufactured products and services.

The change can be provoked either by the decrease in the selling price contracted for, which has been planned at the average value of CZK 20M. per contract and the considered $10 \%$ decrease would have an impact on EBT in the amount of CZK $18 \mathrm{M}$ or by the decrease in the production volume planned in such a way that one single contract that is not executed results in the absolute decrease in EBT by CZK $20 \mathrm{M}$. It is clear that both risks will bring about the same impact on the sales. The increase in material consumption by the same percentage also has an important impact (189\%). The incidental rise in personnel costs or energy consumption should not be neglected either. A relative change in EBT by more than $50 \%$ is considered significant.

\subsection{Scenario Formation and Their Impact on the Company's Financial Plans}

\subsubsection{Scenario Formation}

Scenario formation comes out of the predicted development of risks identified. By their interaction it is possible to arrive at the basic, pessimistic and optimistic scenarios. The development of key risks to be supposed is illustrated in Tab. 3 .

The scenario formation comes out of the assumption that the year 2013 is fixed from the contractual point of view and the risks will have an impact on the company as late as in 2014 and 2015. In the year 2013 contracts for nine big machines were closed, which will generate sales of CZK $172 \mathrm{M}$. $80 \%$ out of the total sales are attributed to the sales of own products and services, while the remaining $20 \%$ refer to the incomes for overhauls and cooperative machine tool operations which account for CZK 43M. The average product price is CZK 19.4M. 
Tab. 3: Development of key risk factors in scenario considered

\begin{tabular}{l|c|c|c|c|c|c|c|c} 
& $\begin{array}{c}\text { Basic } \\
\text { scenario }\end{array}$ & $\begin{array}{c}\text { Basic } \\
\text { scenario }\end{array}$ & \multicolumn{2}{|c|}{ Basic scenario } & \multicolumn{2}{c|}{$\begin{array}{c}\text { Pessimistic } \\
\text { scenario }\end{array}$} & \multicolumn{2}{c}{$\begin{array}{c}\text { Optimistic } \\
\text { scenario }\end{array}$} \\
\cline { 2 - 9 } & $\mathbf{2 0 1 2}$ & $\mathbf{2 0 1 3}$ & $\mathbf{2 0 1 4}$ & $\mathbf{2 0 1 5}$ & $\mathbf{2 0 1 4}$ & $\mathbf{2 0 1 5}$ & $\mathbf{2 0 1 4}$ & $\mathbf{2 0 1 5}$ \\
\hline $\begin{array}{l}\text { Production volume } \\
\text { [pieces] }\end{array}$ & 7 & 9 & 8 & 8 & 7 & 7 & 10 & 10 \\
\hline $\begin{array}{l}\text { Average product price } \\
\text { contracted [M CZK] }\end{array}$ & 17.0 & 19.4 & 21.4 & 23.5 & 18.4 & 19.9 & 21.4 & 23.5 \\
\hline $\begin{array}{l}\text { Overhaul revenues } \\
\text { [M CZK] }\end{array}$ & 51.0 & 43.0 & 48.0 & 51.0 & 37.5 & 47.0 & 53.3 & 58.7 \\
\hline $\begin{array}{l}\text { Material consumption } \\
\text { [M CZK] }\end{array}$ & 110.5 & 109.5 & 120.9 & 130.5 & 87.9 & 116.0 & 130.1 & 140.5 \\
\hline $\begin{array}{l}\text { Energy prices } \\
\text { [CZK/Mwah] }\end{array}$ & 1,250 & 1,350 & 1,404 & 1,460 & 1,437 & 1,531 & 1,404 & 1,460 \\
\hline \begin{tabular}{l} 
Energy costs [M CZK] \\
\hline Services [M CZK]
\end{tabular} & 30.8 & 30.2 & 30.0 & 32.5 & 24.2 & 30.5 & 35.8 & 39.38 \\
\hline $\begin{array}{l}\text { Average employee } \\
\text { salary [thous. CZK] }\end{array}$ & 30.5 & 33.5 & 36.8 & 40.5 & 36.8 & 40.5 & 36.8 & 40.5 \\
\hline
\end{tabular}

Source: own

As for the incomes, scenarios can be characterized as follows: the basic scenario assumes the sales of eight big machines and a price increase by $10 \%$ in each year of the 2014-2015 period compared to 2013. The main reason for the increase in sales rests on the improved quality of products, which was accomplished thanks to innovations of the current technological facilities. The average machine price was CZK 21,340,000 and CZK $23,474,000$ in the years 2014 and 2015 respectively. The incomes for overhauls show the increase thanks to the opening the service centre in Russia.

As opposed to the basic scenario, the pessimistic scenario assumes that saturation of demand for machines in the Czech market will result both in closing fewer contracts and fixing prices which are lower than those assumed in the basic scenario due to the competitors' pressure. The pessimistic scenario assumes closing one contract only in the Czech market and on the whole seven contracts are predicted to be closed in each contractual year (2014 and 2015). An average contracted price decline can be $5 \%$ in the year 2014. In 2015 it is assumed that due to the competitors' pressure the machine price will drop by $15 \%$ as compared to the basic scenario. Incomes from overhauls are developing in proportion to the decrease in service demand.

In the optimistic scenario the company assumes that the impact of machine demand saturation in the Czech market will not influence negatively its sales. The increase in government investments in the technology development in Russia, Belorussia and the Ukraine will positively influence the number of contracts closed in these countries. The assumption of the optimistic scenario is that notwithstanding the strong competition in the foreign market, the production capacity will be fully utilized in each year, which accounts for closing ten contracts in each year of 2014 and 2015 at the price increased by $10 \%$ thanks to the improved product quality (which refers to the basic scenario). In view of the increased product quality, the increase in the average machine price by $10 \%$ is assumed in either year, which represents one of the company's goals. The overhauls income development is positively affected by the operation of the service centre in Russia.

In terms of the costs the scenarios can be characterized as follows: The company purchases material continuously from the approved suppliers depending on the contracts closed. As long as the company fixes a certain 
purchase volume, the supplier offers a volume discount of $3 \%$. The energy consumption is partially invariable (approx. $3 \%$ ), which the company has to cover even in case of no or low production. Yet a prevalent part of the costs is variable and dependent on the production volume. The basic scenario assumes that the energy price will be CZK 1,350/Mwah in 2013 and it will rise by $4 \%$ in the years 2014 and 2015 , which will result in the increase in energy costs. The increase in services is assumed to be $5 \%$ per year. The development of unfavourable risk factors in the pessimistic scenario will have an impact on the material and energy consumption as well. As long as the company purchases a lower quantity of material due to the lower number of contracts closed, the company is not allowed to get a discount and by contrast the material unit price will rise. The increase in the material unit price is supposed to be at the level of volume discount (3\%). Last but not least, a moderate decline in the costs will not be adequate to the steep decline in sales. The increase in energy prices in this scenario is higher than that in the basic one and it is supposed to be $6.5 \%$ in each year of the planned period.

The optimistic scenario reckons on the positive impact of risks on the Material, energy and services consumption. In view of maxi- mizing the machine production output it is necessary to reinforce outsourcing so that the company can meet product delivery timelines. As opposed to the basic scenarios the service costs will rise (which accounts for $15 \%$ of the Material, energy and services consumption in the basic scenario) by $10 \%$ in each year of the period. Simultaneously, energy costs will also rise by $10 \%$ each year. As far as energy prices are concerned, the same development as that indicated in the basic scenario is supposed. Material costs will also increase due to bigger volumes consumed while the prices to be charged for material remaining the same as those stated in the basic scenario. The determination of personnel costs comes out of the assumption that the headcount in all scenarios in both planned period is identical, specifically 67 . Similarly the growth of the average monthly salary of CZK 33,500 in 2013 by $10 \%$ per year for each scenario is assumed.

\subsubsection{The Impact of Scenarios on Both the Company's Financial Plan and Key Indicator ROS}

A different development as per individual scenarios has an impact on the company's financial plan. The development of chosen financial plan items in these scenarios is shown in Tab. 4.

\section{Tab. 4: Development of basic financial plan items in scenarios considered [CZK in M]}

\begin{tabular}{l|c|c|c|c|c|c|c|c} 
& $\begin{array}{c}\text { Basic } \\
\text { scenario }\end{array}$ & $\begin{array}{c}\text { Basic } \\
\text { scenario }\end{array}$ & \multicolumn{2}{|c|}{ Basic scenario } & \multicolumn{2}{c|}{$\begin{array}{c}\text { Pessimistic } \\
\text { scenario }\end{array}$} & \multicolumn{2}{c}{$\begin{array}{c}\text { Optimistic } \\
\text { scenario }\end{array}$} \\
\cline { 2 - 9 } & $\mathbf{2 0 1 2}$ & $\mathbf{2 0 1 3}$ & $\mathbf{2 0 1 4}$ & $\mathbf{2 0 1 5}$ & $\mathbf{2 0 1 4}$ & $\mathbf{2 0 1 5}$ & $\mathbf{2 0 1 4}$ & $\mathbf{2 0 1 5}$ \\
\hline $\begin{array}{l}\text { Sales of own } \\
\text { manufactured products } \\
\text { and services [M CZK ] }\end{array}$ & 169.9 & 215.0 & 236.5 & 260.1 & 186.7 & 234.7 & 266.7 & 293.5 \\
\hline $\begin{array}{l}\text { Material, energy and } \\
\text { services consumption } \\
\text { [M CZK] }\end{array}$ & 141.3 & 167.6 & 180.1 & 193.7 & 140.0 & 176.0 & 198.2 & 213.1 \\
\hline $\begin{array}{l}\text { Personnel costs } \\
\text { [M CZK] }\end{array}$ & 31.4 & 36.1 & 39.7 & 43.7 & 39.7 & 43.7 & 39.7 & 43.7 \\
\hline \begin{tabular}{l} 
EBIT[M CZK] \\
\hline Financial profit [M CZK]
\end{tabular} & -2.1 & -3.0 & -2.9 & -3.3 & -2.9 & -3.3 & -2.9 & -3.3 \\
\hline After-tax profit (EAT) & 6.6 & 4.9 & 9.1 & 11.7 & 0.8 & 0.3 & 19.7 & 23.7 \\
\hline $\begin{array}{l}\text { Pre-tax profit (EBT) } \\
\text { [M CZK] }\end{array}$ & 7.5 & 5.8 & 10.6 & 13.6 & 1.0 & 0.4 & 22.9 & 27.5 \\
\hline
\end{tabular}


Differences in the financial plan items are manifested in Return on sales indicator values (ROS), which were calculated for each year of the planned period considered. ROS was chosen as a metric for the measurement of the extent of fulfilling the company's basic strategic goal. The development of this indicator is shown in Tab. 5.

Tab. 5: Comparison of Return on sales (ROS) development as per individual scenarios

\begin{tabular}{l|c|c|c|c|c|c|c|c} 
& $\begin{array}{c}\text { Basic } \\
\text { scenario }\end{array}$ & $\begin{array}{c}\text { Basic } \\
\text { scenario }\end{array}$ & \multicolumn{2}{|c|}{$\begin{array}{c}\text { Basic } \\
\text { scenario }\end{array}$} & \multicolumn{2}{c|}{$\begin{array}{c}\text { Pessimistic } \\
\text { scenario }\end{array}$} & \multicolumn{2}{c}{$\begin{array}{c}\text { Optimistic } \\
\text { scenario }\end{array}$} \\
\cline { 2 - 10 } & $\mathbf{2 0 1 2}$ & $\mathbf{2 0 1 3}$ & $\mathbf{2 0 1 4}$ & $\mathbf{2 0 1 5}$ & $\mathbf{2 0 1 4}$ & $\mathbf{2 0 1 5}$ & $\mathbf{2 0 1 4}$ & $\mathbf{2 0 1 5}$ \\
\hline EBT [M CZK] & 7.5 & 5.8 & 10.6 & 13.6 & 1.0 & 0.4 & 22.9 & 27.5 \\
\hline $\begin{array}{l}\text { Sales of own } \\
\text { manufactured products } \\
\text { and services [M CZK] }\end{array}$ & 169.9 & 215.0 & 236.5 & 260.1 & 186.7 & 234.7 & 266.7 & 293.5 \\
\hline ROS [\%] & 4.42 & 2.70 & 4.48 & 5.22 & 0.54 & 0.14 & 8.56 & 9.37 \\
\hline
\end{tabular}

Even if the company generates a positive profit in each year according to the pessimistic scenario, EBT, as contrasted to the basic scenario, will drop by $90.35 \%$ and $97.57 \%$ in 2014 and 2015 respectively. It is reflected by a significant drop in Return on sales. This development indicates that the company should examine other variants of the strategic plan as well, e.g. a restriction on investment activities. It is also possible to correct strategic goals, for instance to postpone the establishment of the service centre in Russia.

According to the optimistic scenario, the increase in profit by $115.37 \%$ and $102.43 \%$ in 2014 and 2015 respectively, as contrasted to the basic scenario, will be recorded. Return on sales (ROS) thus safely meets the strategic goal.

\subsection{The Application of Scenarios in the Company's Strategic Management}

The above-mentioned scenarios indicate a potential development in the planned period considered. When pursuing the development of key risks we are allowed not only to judge viability of the strategic goals determined, but also to timely execute relevant provisions, which enable the company to cope with the development that deviates from the original assumptions. In this way scenarios work as a tool of company's flexibility enhancement. This element is important preferably in a period when the development of business environment is turbulent and strategic management must respect this development as long as it wants to remain an effective tool. However, the identification of potential environment development directions and the assessment of their impacts on the company's performance do not complete the strategic planning process. The managerial competences are necessary for the subsequent implementation of decisionmaking procedures. An emphasis should be also placed on working with the strategic options (variants) that model the impact of fundamental managerial decisions within scenarios. An emphasis should be also laid on looking for optimum utilization of sources in order to ensure future competitiveness.

\section{Benefits and Shortcomings of Scenario Approaches}

\subsection{Benefits of Scenario Approaches}

The scenario approach contributes, to a large extent, to the deeper understanding of the influence of individual risks on both the strategic plan and investment project variant outcomes in terms of relevant assessment criteria. The importance of scenario development does not consist in accuracy and reliability of long-term predictions, but in better recognition of mechanisms which control the development of business environment and their acquirement by the team of investment analysts. This process 
enhances the probability of timely recognition of upcoming critical discontinuities and their transformation into business opportunities which are instrumental in fulfilment of company's strategic goals.

The scenario approach can be used both in the preparation of decisions, their choice and implementation. In the former case the use is aimed at the elaboration of new company's concepts, the improvement of strategic management, the increase of company's perception of changes both in business environment and employees motivation or employees consideration. In the latter case the scenario use results in the deeper recognition of the situation, the strategy formulation and its assessment or the formulation of judgements and the preparation of proposals. The scenario approach leaves a single prospective development out of account and takes into consideration more alternatives of future development of business environment. In this way the scenario approach creates an alternative to the concept of "business as usual" and creates space for more complex understanding of uncertain future. Robustness of investment projects as well as their extent of flexibility from the point of view of the number and the extent of scenarios which are covered by this flexibility also belong to the important benefits of scenarios.

The application of scenarios in risk management as tools for the support of preparation and implementation of strategic plan and investment projects risk mitigation provisions cannot be omitted. Similarly, the preparation of contingency provisions, supposing that important and untreated risks occur, must also be properly highlighted. A limited demand for software support can be considered as a certain technical benefit of the scenario approach. Basically MS EXCEL is sufficient for mastering the scenario approach.

To illustrate the broad applicability of scenario approach, other important applications can be presented. The following examples can be given:

- Investment portfolio development in an important Iranian company which is composed of five business branches as petrochemistry, minerals quarry and their processing, cement production, machinery, financial and trade services. Typical features of this application were integration of scenarios, multicriteria assessment methods PROMETHEE and linear programing [16],

- Investment projects risk assessment in the Czech Republic which were taken from branches of chemistry (Fatty acid methyl ester - FAME production to be a component of biodiesel), pharmaceutical industry (antiglaucoma agent project for the treatment of glaucoma) and energy (solar power station construction project [30].

- Identification and assessment of new business opportunities. The objective was the application of the above-mentioned scenarios for searching for new opportunities found in the intersection point of processing industry and downstream branches [27].

- Support of development strategy elaboration by means of the integration of scenarios and operational research models with applications referring to energy [4], renewable energy sources utilization [20] and fishing [3].

- Research, development and clinical testing of new drugs represent considerably costly, time consuming and highly risky process. These attributes manifest themselves both in research and development phase (testing of thousands substances) and clinical testing (evaluation of new drug effects in clinical practice), when incidental side effects may even imply refusal of its registration [1].

- Organizational goals modelling or identification of prospective business targets [31].

- Scenario planning for climate strategy development by means of the application of questionnaire surveys combined with Delphi method (the examination of mutual social and economic factors and trends), dynamic fuzzy cognitive maps (e.g. the examination of mutual links among these factors) and Saaty method of multicriteria evaluation (the determination of key factors essential for scenarios formation) [2].

- Decision support characterized by severe impacts concerning the third set of sailing channel in Panama Canal [22].

- Support of planning and decision making with a view to the economic recovery during the recession period [22]. 
Only then is scenario approach effective, when it is conceived as a continuous and steady process. Under these circumstances managers are compelled to re-evaluate their view of business environment development and include effects which would have been otherwise omitted.

The interconnection of scenarios with the consideration about the future, including the application of the aforementioned early warning systems, provides signals on what possible scenario may come into effect and therefore it enables timely reaction to this development. Consequently it helps reduce an occurrence of severe problems which require crisis management execution. Transparency and communicability of every scenario is a prerequisite for a speedy and effective execution of the change. Business practice experience shows that inertia thinking ("things go in the same way as before"), incapability to perceive potential changes in business environment as well as their impacts on both the company and its core business resulted in endangering the very existence of even very successful companies in the past. (Copy machines producer Xerox can be set as an example).

\subsection{Shortcomings and Restraints of Scenario Approaches}

Shortcomings of scenario approaches are manifested especially in situations, where a great many risks exist that may furthermore acquire a great number of values. The continuous character of risks represents a limit case. Respecting a restricted number of risks only or substitution of continuous risks by discreet ones with a small number of values implies elaboration of lower number of scenarios, which do not provide an entire picture about the risks of the plan or project. Such a set of scenarios is quite often not representative.

If this is the case, then scenario approach cannot be used for the risk analysis of strategic plans or investment projects and it is inevitable to resort to more sophisticated tools, such as the Monte Carlo simulation [19], [24], and [28]. A combination of scenarios with the Monte Carlo simulation results in the concept of conditional risk analysis, which can also be useful [9]. Gugan [15] sees barriers to a fullyfledged scenario application in the set of causes, the most important being too narrow focus of scenarios, which do not cover their global extent, elaboration of scenarios that are, from the company's point of view, out of the possible impact scope. Among other barriers low engagement of the management team and even a substitution of scenarios for predictions should be ranked. The reservation, which is of some relevance, is that the most important risk factors are unpredictable when being assessed from the point of view of past and present times. This may imply the so-called tunnel effect, which comes out of the past and current well-known risk factors (prices, demand, costs, exchange rates etc.) and weakens sensitivity to searching for new, in the past unknown, risk factors [8]. According to this opinion, the main risk of scenario application rests on fact that it may result in the quantification of irrelevant risks. These objections are worth considering, since the aforementioned shortcoming can, to some extent, be weakened by the emphasis placed on the risk identification phase and its quality.

Another shortcoming, which hampers the scenario application, is the fact that this method lacks a validation tool that would enable the assessment of scenarios proposed. Typically, it is questionable if the decision maker actually has the most appropriate scenarios at disposal. Moreover, as per Mensonides [23], scenarios often miss internal logic, trustworthiness and dynamics. Scenarios very frequently fail in situations, where they are about to recognize all mutual links among heterogeneous subjects, activities and sources.

The applicability of scenarios is contingent upon their easy communication towards subjects, which decide about their application. As long as scenarios are too complex and their conclusions can be interpreted with difficulties only, then advantages of scenario approach may be turned into disadvantages and scenario approach may be refused as a principle.

\subsection{Success Factors of Scenario Application in Strategic Management}

The success of formation and application of scenarios are influenced by more factors, the most important are [6]:

- Commitment of top management: Without the support of top management the scenario formation is usually one-off activity; 
- Engagement of creative employees from all company hierarchies as well as external specialists in scenario elaboration;

- Collecting information for scenarios elaboration from multiple sources, typically both internal and external ones;

- Respecting the requirement of internal consistency and realistic nature of each scenario (behind each scenario there should be a meaningful story);

- Respecting conflict representativeness requirements of the set of scenarios elaborated upon their restricted number;

- Avoiding tendency to trust too much to the capability of predicting the future and rely on logic consideration and supporting analysis which are based on facts;

- Neither being fixed to adaptation to already composed scenarios nor missing out the possibility of actively influencing the future;

- Continuous monitoring of the development of environment and depending on its results the ongoing updating of the set of scenarios composed;

Respecting these factors can considerably contribute to the application of scenarios as an important tool for the strategy development, strategic planning and strategic investment decision making.

\section{Conclusion}

The scenario application, while respecting risks known, significantly enhances the quality of strategic management which contributes to better company's stability, determination of realistic goals and, finally, to the increase of its market value. It is essential that the scenario approach abstracts from the simplistic view of the future to be personified by one possible environment development and takes into consideration the multiple development of the environment. This allows thinking and viewing strategies and strategic plans in more stratified manner, especially from the point of view of their possible outcomes. The scenario approach is applicable both in the stage of decision making and the stage of decision preparation. In the former case, scenarios are used as tools for the strategy and strategic plan variants selection or, as the case may be, for the selection of key investment projects variants (for more see e.g. [10], [21]). In the latter case, scenarios enable a deeper recognition of the situation and support the strategy or strategic plan variants elaboration. These plans are either sufficiently robust or flexible so that the company may react to the change of a situation and development can be in consonance with other scenarios. This flexibility is supported by the scenario interconnection with early warning systems and strategic risk management. The scenario approach proves its benefits even in communication with company's stakeholders, since all possibilities and company's potential growth in the context of current business environment development can be bolstered up by arguments. Last but not least, the scenario approach is beneficial to the determination of controlling value limits in controlling processes. The example of a scenario application in a specific company shows that the company management has to draw a great deal of attention to scenario planning within the framework of strategic planning activities. The enhanced quality of decision-making processes, which is reflected in the effectiveness of company's tactical and operational management, is considered to be the key benefit.

This paper is one of outcomes of the research project called Competitiveness which is solved by the Faculty of Business Administration at the University of Economics in Prague. This project, recorded under the reference number VŠE IP 3000040 (institutional grant) is subsidized by the Ministry of Education of the Czech Republic.

\section{References}

[1] BENDA, N., BRANSON, M., MAURER, W., FRIEDE, T. Aspects of Modernizing Drug Development Using Clinical Scenario Planning and Evaluation. Drug Information Journal. 2010, Vol. 44, No. 3, pp. 299-315. ISSN 2168-4790.

[2] BILOSLAVO, R., DOLINŠEK, S. Scenario planning for climate strategies development by integrating group Delphi, AHP and dynamic fuzzy cognitive maps. Foresight. 2010, Vol. 12, No. 2, pp. 38-48. ISSN 1463-6689.

[3] BRYANT, J., MEADOWS, M., MORECROFT, J., O'BRIEN, F. Gone fishing: a case study. In: O'BRIEN, F., DYSSON, R.G. (Eds.). Supporting Strategy: Frameworks, Methods, and Models. Chichester: John Wiley \& Sons, 2007. pp. 369393. ISBN 978-0-470-05717-9. 
[4] BURT, G. Towards the integration of system modelling with scenario planning to support strategy: the case of the UK energy industry. Journal of the Operational Research Society. 2011, Vol. 62, Iss. 5, pp. 830-839. ISSN 0160-5682.

[5] CLEMENS, P.L. Event Tree Analysis. 2nd ed. Sverdrup, 1990. 13 p. Available also from: http://www. fault-tree.net/papers/clemens-event-tree.pdf.

[6] COURTNEY, H. Decision Driven Scenarios for Assessing Four Levels of Uncertainty. Strategy and Leadership. 2003, Vol. 31, Iss. 1, pp. 14-22. ISSN 1087-8572.

[7] FOSTER, M.J. Scenario Planning for Small Business. Long Range Planning. 1993, Vol. 26, No. 1, pp. 123-129. ISSN 0024-6301.

[8] FOTR, J., KISLINGEROVÁ, E. Integrace rizika a nejistoty do investičního rozhodování a oceňování. Politická ekonomie. 2009, Vol. 57, Iss. 6, pp. 801-826. ISSN 0032-3233.

[9] FOTR, J., PÍŠEK, M. Exaktní metody ekonomického rozhodování. 1. ed. Praha: Academia, 1986. 165 p. ISBN 21-013-86.

[10] FOTR, J., PLEVNÝ, M., ŠVECOVÁ, L., VACÍK, E. Multi-Criteria Project Portfolio Optimization under Risk and Specific Limitations.

E+M Ekonomie a Management. 2013, Vol. 16, Iss. 4, pp. 71-88. ISSN 1212-3609.

[11] FOTR, J., ŠVECOVÁ, L., HRŮZOVÁ, H., RICHTER, J. Manažerské rozhodování. Postupy, metody a nástroje. 2. ed. Praha: Ekopress, 2010. ISBN 978-80-86929-59-0.

[12] FOTR, J., SOUČEK, I. Investiční rozhodování a ř́zení projektů. Praha: Grada Publishing, 2011. ISBN 978-80-247-3293-0.

[13] FOTR, J., VACÍK, E., SOUČEK, I., ŠPAČEK, M., HÁJEK, S. Tvorba strategie a strategické plánování. Teorie a praxe. Praha: Grada Publishing, 2011. ISBN 978-80-247-3985-4.

[14] GRAY, P. Competitive Intelligence. Business Intelligence Journal. 2010, Vol. 15, No. 4, pp. 31-37. ISSN 1918-2325.

[15] GUGAN, A. Successful Scenario Planning [online]. JISC infoNet, 2008-11-19 [cit. 2013-11-15]. Available from: http://www.jisc.ac.uk/publications/ generalpublications/2008/scenarioplanningflyer.aspx. [16] HANAFIZADEH, P., KAZAZI, A., BOLSHANI, A.J. Portfolio design for investment companies through scenario planning. Management Decision. 2011, Vol. 49, No. 4, pp. 513-532. ISSN 0025-1747. [17] HEIJDEN, Van Der, K. The Art of Maverick Thinking. Scenario \& Strategy Planning. 1999, Vol. 1, Iss. 1, pp. 19-23. ISSN 1466-4062.
[18] HEIJDEN, Van Der, K. Scenarios, the Art of Strategic Conversation. Chichester: John Wiley \& Sons, 2005. ISBN 0-470-02368-6.

[19] HNILICA, J., FOTR, J. Aplikovaná analýza rizika ve finančním managementu a investičním rozhodování. 1. ed. Praha: Grada Publishing, 2009. 262 p. ISBN 978-80-247-2560-4.

[20] HOWICK, S., ACKERMANN, F., ANDERSEN, D. Linking event thinking with structural thinking: methods to improve client value in projects. System Dynamics Review. 2006, Vol. 22, No. 2, pp. 113-140. ISSN 1099-1727.

[21] KRACÍK, L., VACÍK, E., PLEVNÝ, M. Application of the multi-project management in companies. In: Proceedings of the 11th International Conference on Liberec Economic Forum 2013. Liberec: Technical University of Liberec, 2013. pp. 316-324. ISBN 978-80-7372-953-0.

[22] MARREN, P.B., KENNEDY Jr., P.J. Scenario planning for economic recovery: short-term decision making in a recession. Strategy \& Leadership. 2010, Vol. 38, No. 1, pp. 11-16. ISSN 1087-8572. [23] MENSONIDES, M., HUISMAN, B., DIGNUM, V. Towards Agent-Based Scenario Development for Strategic Decision Support. In: Lecture Notes in Computer Science. Agent-oriented Information Systems IV. 2008, Vol. 4898, pp. 53-72. ISBN 9783-540-77989-6.

[24] MUN, J. Modelling Risk. 2nd ed. New York: John Wiley \& Sons, 2010. ISBN 978-0-470-59221-2. [25] O'BRIEN, F., MEADOWS, M., MURTLAND, $M$. Creating and using scenarios - Exploring alternative possible futures and their impact on strategic decisions. In: O'BRIEN, F.A., DYSON, R.G. (Eds.). Supporting Strategy: Frameworks, Methods and Models. Chichester: John Wiley \& Sons Ltd., 2007. pp. 211-247. ISBN 978-0-47005717-9.

[26] PEARSON, I., LYONS, M. Re-evaluation In An Age of Uncertainty. Scenario \& Strategy Planning. 1999, Vol. 1, Iss. 1, pp. 3. ISSN 1466-4062. [27] PIIRAINEN, K., KORTELAINEN, S., ELFVENGREN, K., TUOMINEN, M. A scenario approach for assessing new business concepts. Management Research Review. 2010, Vol. 33, No. 6, pp. 635-655. ISSN 2040-8269.

[28] PRAKASH, A. Scenario planning for service quality: A Monte Carlo simulation study. Journal of Strategy and Management. 2012, Vol. 5, Iss. 3, pp. 331-352. ISSN 1755-425X.

[29] ŠPAČEK, M. Scénářové a simulační př́stupy $v$ analýze rizika investičních projektů. Doctoral 
dissertation. Prague, 2009. University of Economics.

[30] TESSUN, F., HERMANN, A. Harnessing Potential Future. Scenario \& Strategy Planning. 1999, Vol. 1, Iss. 1, pp. 8-12. ISSN 1466-4062.

[31] ZORIC, J., BRAEK, R. Scenario based techno-business. Analysis of service platforms and their service portfolios. Telecommunication System. 2011, Vol. 46, Iss. 2, pp. 95-116. ISSN 1018-4864. doc. Ing. Emil Vacík, Ph.D. University of West Bohemia Faculty of Economics

Department of Business Administration and Management vacik@kpm.zcu.cz

prof. Ing. Jiří Fotr, CSc. University of Economics, Prague Faculty of Business Administration Department of management fotr@vse.cz

Ing. Miroslav Špaček, Ph.D., MBA University of Economics, Prague Faculty of Business Administration Department of management Miroslav.spacek@vse.cz

Ing. Ivan Souček, Ph.D. Institute of Chemical Technology in Prague Faculty of Chemical Engineering Department of Economics and Management of Chemical and Food Industry ICT Prague isoucek@email.cz 


\title{
Abstract
}

\section{SCENARIOS AND THEIR APPLICATION IN STRATEGIC PLANNING}

\author{
Emil Vacík, Jiří Fotr, Miroslav Špaček, Ivan Souček
}

The article deals with the concept of scenario planning. Scenarios, as opposed to usual prediction methods, are focused on the identification of discontinuities in the development and help the organization cope with sudden changes and noticeably contribute to its survival. Contemporary methods of scenarios construction work on need to ensure flexibility of the strategic plan and get the firm ready for a quick reaction when set trigger points specifying the corresponding scenario come to pass. Processing of business environment information, known as Business Intelligence, becomes necessity. Based on the methodological platform, it describes in detail the stepwise process of scenario construction. The very process of scenario elaboration goes through six basic steps, Identification of risk factors and determination of their importance; Selection of key risks which, according to the company's opinion, fundamentally influence fulfilment of strategic goals; Formulation of basic scenarios and testing their consistency; Determination of probability of scenarios occurrence and Performing a "gap analysis" for the sake of determining the extent of strategic goals fulfilment.

There are various types of scenarios which might be respected due to the development of entrepreneurial environment introduced and discussed. Respecting the indicated risk factors and their influence on key risks of the financial plan, the spread of scenarios is being drafted. It is typical of business practice to work with 3-4 scenarios. Besides determining the impact of a risk on the firm's performance (the rate of fulfilling set strategic goals), the probability assessment of each scenario is also necessary. Outputs from constructed scenarios are to be worked up into a particular strategic option, which may be used as a qualified base for the strategic decisionmaking process. The practical application shows how the methodology used raises flexibility in strategic planning of the firm.

Key Words: Scenarios, strategic planning, investment decision making, risk, risk analysis, Monte Carlo simulation.

JEL Classification: M21, O22.

DOI: 10.15240/tul/001/2014-3-010 